

\section{MASSEKULTUR OG KABLER: REDAKTIONELT FORORD}

Som de store europæiske lande - Vesttyskland, Storbritannien og Frankrig - har ogsa Danmark nu en kabelpolitik. Dette markerer Massekultur \& Medier med et temanummer om Massekultur \& Kabler.

D. 21. februar 1983 afleverede mediekommissionen sin dobbeltbetzenkning om kabelproblematikken og om fremforelse af udenlandsk fjernsyn til statsminister Poul Schlüter. Med hensyn til kabelproblematikken anbefalede den samlede mediekormmission på ét medlem næer "... at der med henblik på udviklingen at et kommende landsdrkkende bredbandsnet hurtigt skabes de nodvendige forudsatninger for etableringen af et sakaldt hybridnet, der dels bygger på teleselskabernes overordnede net, dels forudsetter en vis styring af udviklingen af fællesantenneanlaggene og forbindelsesnettene mellem dem."

Imidlertid nedsatte regeringen allerede d. 23. december 1982 et tvarministerielt udvalg om informationsteknologien. Udvalget skulle, ifølge sit kommissorium, "... som sin første opgave i løbet af foraret 1983 forberede den politiske beslutning om evt. etablering af bredbåndsnet." Herudover er det meningen, at udvalget skal fortsatte med at udarbejde forslag, der - som det hedder - "kan støtte gennemf relsen af en samlet informationspolitik." Det drejer sig om offentlige investeringer, ivarksattelse af udviklingssamarbejde og initiativer pa forsknings- og uddannelsesomradet. Og endelig skal udvalget se pa mulighederne for en liberalisering inden for bl.a. teleomradet. Udvalget taller reprasentanter for statsministeriet, budgetdepartementet, administrationsdepartementet (som varetager formandsskab og sekretariatsfunktion), ministeriet for offentlige arbejder, kulturministeriet, industriministeriet, undervisningsministeriet, arbejdsministeriet og miljøministeriet.

D. 10. maj afleverede udvalget via ministeren for offentlige arbejder sin redeg $\phi$ relse om udviklingslinier for telekommunikationsnettet. I redegørelsen deles udviklingen op i tre faser. Frem til 1. november 1983 skal televirksomhedeme udarbejde en generel plan for hybridnettets tilvejebringelse. Planen skal oplyse om strukturen for det overordnede lysledernet, om rammeme for anlag og ombygning af fallesantenneanlag, og om forbindelsesnettene til og imellem disse fallesantenneanlag. Fra slutningen af 1983 og - antageligvis - ca. 5 ar frem skal hybridnettet 
anlægges, dvs. det net som består af en blanding af et overordnet lysledernet (i $\not$ vrigt vil visse strakninger sikkert i starten blive betjent af radiokæder) og traditionelle coaxialbaserede fællesantennenet med træstruktur. I tredje fase, dvs. fra slutningen af $1980^{\circ}$ erne, forventer man at etableringen af det integrerede bredbåndsnet skal foretages.

Bagved regeringsredegørelsens forslag gemmer der sig en rakke problemer ved den kommende kabeludbygning. Nogle af dem afslører sig selv; men andre sættes bedst i relief ved at sammenligne med andre landes kabeludbygningsplaner, in casu med den borgerlige Thatcher-regerings planer i England og den socialistiske Mitterandregerings planer i Frankrig.

For det første er det bemærkelsesværdigt for den danske regeringsredeg $\phi$ relse, at teleadministrationerne har vundet en éntydig sejr: Det er de tre telefonselskaber og P\&T, der skal fremføre TV-signaler helt ud til de enkelte fællesantenneanlæg. Og ovenikøbet angiver man en maksimumstørrelse for fremtidige (?) fællesantenneanlæg pa ca. 1000 tilslutninger. Denne holdning til teleadministrationernes rolle ligner mere den socialistiske franske end den borgerlige engelske: I Frankrig spiller post-, telefon- og telegrafvesnet PTT en dominerende rolle, mens man i England lader kabeludbygningen foreg̊̊ på privat basisa Dér opererer man med privatejede antennesystemer på op til 250.000 tilslutninger som grundelementet i det fremtidige britiske kabelsystem.

Den danske, borgerlige regering er således ikke særlig liberalistisk mht. anlæggelse og ejerskab af kabler. Det kan umiddelbart se ud til, at man har besluttet sig for til gengæld at markere den liberalistiske ideologi på det mediepolitiske område. Overalt i Europa diskuterer man indgående, hvordan man tackler problemet med de kommende kommunikationssatellitter. Disse kommunikationssatellitter er konstrueret med henblik på varetagelse af teletrafik, og de skal således administreres af post- og telegrafvasenerne. Men det har vist sig, at disse satellitters overskydende kapacitet kan bruges til at distribuere tv-signaler med: Et hvilket som helst indenog udenlandsk privat selskab kan købe sig distributionsplads via et af de nationale P\&T'er. Heroverfor kommer de nationale regeringer f $\phi$ rst ind i billedet $\mathrm{i}$ allersidste instans; deres indflydelse vil i givet fald vare reduceret til udstedelse af eventuelle forbud mod at modtage kommunikationssatellittens programmer. Kommunikations- 
satellitten indebarer saledes en fare for, at de enkelte nationers tilrettelaggelse af samlede mediepolitikker slas i stykker. Dette har som sagt fremkaldt alvorlige overvejelser i mange europæiske lande, og Thatcher-regeringen har anvist en forholdsvis restriktiv politik med det erklarede formal at beskytte de eksisterende, velanskrevne, engelske TV-selskaber. Men på dette punkt overhaler man I Danmark de engelske kolleger højre om: Den danske regering "... onsker at der skal vare mulighed for at se programmer, der sendes via kommunikationssatellitter" og tilf $\emptyset$ jer: "Der er ingen grund til at tøve med denne beslutning*"

Man kan herudover pege pa en rakke andre problemer:

- Hvilken rolle skal kommunerne spille i udbygningen og administrationen af de kommende kabelsystemer? At de skal spille en rolle understreger regeringsredeg $\phi$ relsen; men den afslфrer ikke hvilken. Hvad angår dette spфrgsmal kan man henvise til kabelpolitikken i Frankrig. Ogsa her spiller telefonselskabet som sagt den dominerende rolle hvad angår nedlaggelse og teknisk drift af kableme. Til gengald har man opstillet en styringsmodel med henblik på en decentral og alsidig regulering af den daglige brug af kableme. Dette sporgsmål bør også tages op i Danmark for at undgå at den for $\phi$ gede elektroniske fjerntrafik bliver ensbetydende med for gget elektronisk fjernkontrol.

- Hvordan skal betalingen af kabelsystemet ske? Man har tilsyneladende accepteret det, der 1 England med overraskende arlighed er blevet kaldt "paradoksproblemet", nemlig at det er de private husholdninger, der via et forøget TV-konsum skal finansiere et kabelsystem, som i lige sa hфj grad har til formal at forbedre den erhervsrettede telekommunikation.

Formalet med dette nummer at Massekultur \& Medier er at give laserne en chance for - som ovenfor antydet - selv at satte dansk kabelpolitik i en slags europzisk reliet.

Derfor indledes nummeret med en gengivelse af Ministeren for offentlige arbejders redegørelse til folketinget om udviklingslinier for telekommunikationsnettet og med en analyse af mediekommissionens betankning om bredbândsproblematikken.

Derefter følger en gennemgang af kabelpolitikken i England, Frankrig, Vesttyskland og Italien. 
Tilsidst i nummeret finder man nogle anmeldelser af de centrale dokumenter i den danske kabel- og informationsteknologidebat. Mange af de kabelberegninger, som er fremkommet det sidste års tid, har tilsyneladende haft det formal at virke som murbrækkere og håndvåben i den kabelpolitiske debat. Ligeledes har vi medtaget en anmeldelse af det danske teledatafors $\emptyset$ gs f $\phi$ lgeforskningsrapport, fordi vi her har et eksempel p§, hvilken (efter redaktionens mening utilstrakkelig) rolle $1 \emptyset$ lgeforskningen spiller i teleadministrationernes udvikling af nye informations- og kommunikationstekniske systemer.

I $\phi$ vrigt kan vi henvise til en anden publikation, der behandler emner der er beslægtet med dette nummers indhold. Bogen hedder TeleVisioner. Den er redigeret af Anker Brink Lund, Ole Prehn og Jørgen Poulsen (Teknisk Forlag, oktober 1983). Isar b $\phi r$ vi næune de to artikler af Anne Lund og Frands Mortensen om beslutningsprocessen bag vedtagelsen af dansk bredbåndspolitik, "Spillet om bredbåndsnettet" og "Den fiberfixede mediepolitik" samt den redaktionelle artikel om "Medieteknik".

(Redigeringen af dette nummer blev afsluttet d. 1. juni 1983). 


\section{DOKUMENT}

MINISTERIET FOR OFFENTLIGE ARBEJDER

10. mai 1983.

Ministeren for offentlige arbejders redegørelse til folketinget om udviklingslinier for telekommunikationsnettet

1. Mediekommissionens forslag og baggrunden herfor

1 slutningen af februar modtog regeringen mediekommissionens betzenkning om kabelproblematikken og fremf $\emptyset$ ring af udenlandsk fjernsyn. Den samlede kommission, pa nar eet medlem, anbefaler, at der hurtigt skabes de nфdvendige forudsatninger for etablering af et landsomfattende fordelingsnet, og for at udviklingen pa fllesantenneomrádet og for forbindelsesnettene mellem anlæggene styres pa en made, der giver mulighed for en hensigtsmassig udvikling af det nuvarende telenet hen imod et landsdzkkende integreret bredbåndsnet.

Regeringen er enig med mediekommissionen i emnets mediepolitiske betydning og $i$, at udviklingen pa telekommunikationsomradet har vide perspektiver for samfundsudviklingen, industripolitisk, beskaftigelsesmassigt og strukturmassigt bade for den private og den offentlige sektor.

Den tekniske udvikling giver telekommunikationen nye anvendelsesmuligheder, og betæenkningen behandler pa denne baggrund de mulige udviklingslinier for landets forsyning med den nodvendige infrastruktur til dakning af kommende behov for telekommunikation i bred forstand. Hertil hører den tekniske opgave at fremfore fjernsynssignaler fra udenlandske sendestationer saledes, at en større del af befolkningen end nu kan fa mulighed for at modtage disse programmer. 